International Journal of Social Science And Human Research

ISSN(print): 2644-0679, ISSN(online): 2644-0695

Volume 04 Issue 11 November 2021

DOI: $10.47191 / \mathrm{ijsshr} / \mathrm{v} 4-\mathrm{i} 11-46$, Impact factor-5.586

Page No: 3379-3383

\title{
The Major Phases and Characteristics of the Development of Legal Regulation Pertaining the Provision of Interactive Public Services in the Republic of Uzbekistan
}

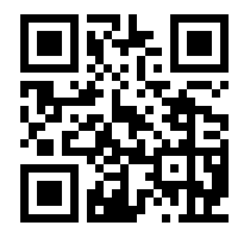

\author{
Laviza Iskhakova, \\ Senior researcher of the Institute of State and Law of the Academy of Sciences of the Republic of Uzbekistan
}

\begin{abstract}
The article is devoted to the review and analysis of legislative acts in the Republic of Uzbekistan which regulate the provision of interactive public services. The article also focuses on the main historical stages of the development of the legal regulation of electronic public services from the moment of their emergence to the present day, the connection of this process with the development of technologies and other factors, as well as the question of institutional and legislative improvement of egovernment management in Uzbekistan.
\end{abstract}

KEYWORDS: interactive public services, E-government, a unified portal for the provision of interactive public services, the Agency of Public Services, the Regulation of electronic Public Services.

\section{INTRODUCTION}

Due to the widespread utilization of information and communication technologies (further - ICT) in public administration, the concept of "public service" is included in the everyday life of legal science and practice. This concept reflects the emergence of new client-oriented relations between the state, citizen and business along with the changing paradigm of interaction between the state and the individual and the rapid technological development of society. It was from this moment, or rather from the beginning of the 2000s, that ICT turned from a technical tool into a factor of changing social relations in society, which could not but affect the transformation of public administration, actively using such an organizational and technological form as electronic government, providing automation of the interaction of state bodies with each other, speed, openness and transparency of management processes, as well as providing citizens and businesses with the necessary public services. Therefore, when we analyze e-government, we encounter the need to understand how e-government services are provided and vice versa, the analysis of the procedure for the provision of such services is an indicator of the level of development of e-government in the country.

As stated by the researchers, the implementation of e-government involves a managerial revolution and, thanks to technology, creates favorable conditions for institutional and political reforms (1).

The most important tool for the effective functioning of e-government is its legislative regulation, which includes two directions: the first is the definition and delimitation of the powers of state bodies that create an institutional mechanism of egovernment; the second is the formulation of policies, laws and regulatory frameworks for issues such as electronic public services, security and protection of personal data, access to information. The Government should monitor this specific national legislation for its compliance with international treaties and best international practices (2).

In this small retrospective analysis of the development of legal regulation of the provision of electronic public services in Uzbekistan, the author tried to trace the evolution of this process, to identify the main trends and problems arising in the provision of these services in the legislation of Uzbekistan.

\section{INTERNATIONAL DOCUMENTS AND PROGRAMS}

The international documents of the United Nations and the International Telecommunication Union (further - ITU) devoted to the formation of the information society contain specific recommendations on how, with the help of what mechanisms and actions and on what principles the information society should be formed in various countries of the world. These are recommendations of technological, financial, economic, organizational, legal and ethical nature, adopted by ITU in 2003 and 2005, have not lost their relevance to this day. This is about the Geneva Declaration of Principles and the Geneva Plan of Action for the Formation of the Information Society of 2003, as well as the Tunisian Program and Commitments of 2005, which allowed States to develop electronic strategies and programs for the development of information technologies within the country and their coordination and development at the global level (3). 


\section{The Major Phases and Characteristics of the Development of Legal Regulation Pertaining the Provision of Interactive Public Services in the Republic of Uzbekistan}

It should be emphasized that Uzbekistan, as a member of ITU, joined both international programs in 2003 and 2005 and used a lot of useful international documents in the creation and implementation of its own national programs for the digital transformation of the economy and public administration.

In 2014, ITU in Geneva at the WSIS+10 High-level Event (WSIS+10) extended the Geneva and Tunis Programs and approved two documents "WSIS+10 Statement on the Implementation of WSIS Decisions" and "The concept developed by WSIS+10 for the period after 2015".

The UN General Assembly, based on the review of the implementation of the WSIS decisions, adopted resolution A/70/L.33 in December 2015, which reaffirmed the commitments made in Geneva (2003) and Tunis (2005), and recognized the need to continue working together to implement the WSIS concept for the period after 2015, as well as the role of the WSIS process in the implementation of the Sustainable Development Goals.

These documents emphasize that the State is crucial in ensuring the access to ICT and the development of electronic services. The task of creating a reliable, competitive, non-discriminatory legal and regulatory environment for the development of electronic services is assigned to public administration bodies.

These legal conditions for the use of ICT should be based on orderly administrative procedures (4). It also emphasizes that e-government can support sustainable development by promoting the effective provision of public services to all people, ensuring transparency, participation and cooperation (5).

\section{STAGES AND DEVELOPMENT OF NATIONAL LEGISLATION ON ELECTRONIC PUBLIC SERVICES}

The first regulatory legal acts on the provision of interactive public services were adopted in Uzbekistan in 2005: the Decree of the President (6) and in 2007 - the Decree of the Cabinet of Ministers (DCM) of the Republic of Uzbekistan (7). These documents introduced the concept of "interactive public service" into legal circulation for the first time. According to the Regulation on Interactive Public Services using Information and Communication Technologies, approved by the DCM No. 181 of August 23, 2007, the goals, objectives and conditions for the provision of these services, regulations and register maintenance, as well as the need to develop uniform standards and requirements for them were determined. Due to the fact that the approach to solving these tasks was technological and the main tasks were assigned to the Uzbek Agency for Communications and Informatization (the predecessor of the current Ministry for the Development of Information Technologies and Communications of the Republic of Uzbekistan - hereinafter "Mininfocom"), this Provision was basically a technical act and could not be otherwise. Interactive public services at that time existed only on paper, in a project, and they had to be created. Although the mentioned Provision has already lost its legal force, its historical and legal significance is important, because it first introduced the concept of "interactive public service", which began to be actively applied and helped legislation and practice develop in the right direction.

The process of forming the legal foundations of interactive public services from this moment on goes both at the level of laws and by-laws. It should be noted that this process could not be objectively accelerated before the real introduction of ICT and new technologies into social life and public administration in Uzbekistan. Taking into account that it was also connected with expensive state investment projects and the choice of a model of technological development, legal regulation lagged behind the actual development of digitalization in the country.

In the period from 2003 to 2007, the foundation was laid in Uzbekistan for the legislative introduction of ICT into public administration through the adoption of such laws as "On Informatization", "On electronic document management", "On electronic digital signature", and "On electronic payments". In addition, state programs have been adopted to computerize and equip state institutions, and a large-scale digitization of the fixed telecommunications network has begun.

From 2008 to 2014, there was an active introduction of internal information systems and software products in government structures, the provision of information and reference electronic services, in particular, a government portal gov.uz was created, which for the first time allowed citizens to apply to government agencies in electronic format to receive public services. Almost all government agencies have launched their websites on the Internet, the provision of one-way electronic services (submission of electronic applications, appeals, requests, etc.) has been launched. Also during this period, rapid development of mobile communications was noted, which resulted in an increase in the number of users.

The adoption of the laws "On Appeals of Individuals and Legal Entities" (2014) and "On e-commerce" (2015) stimulated the development of interaction between citizens and civil society structures with the state, as well as the creation and development of e-commerce infrastructure. During this period, it can be said that ICT in Uzbekistan is becoming a factor not only in the economic, but also in the social life of society.

Since then, a lot of work has been done in the legal, technical and technological sense, a long and difficult path of information technology development has been passed for the country, a certain technical basis has been created for the creation and functioning of an electronic government system, without which electronic public services could not exist. 


\section{The Major Phases and Characteristics of the Development of Legal Regulation Pertaining the Provision of Interactive Public Services in the Republic of Uzbekistan}

The subject of our retrospective analysis is the formation of the legal foundations for the provision of interactive public services as a public law institution, and therefore we will focus on the main stages and documents of this formation, which has not yet been completed.

Today, Uzbekistan has created a certain legislative and institutional framework for the provision of these services and it continues to develop. Accordingly, a unified state policy is being implemented in the field of administrative procedures and the provision of public services.

An important stage in the development of legislation was the adoption in 2015 of the Law of the Republic of Uzbekistan "On Electronic Government" (8). The development of the law was preceded by years of implementation of state programs for the development of the national telecommunications system and information systems, which were based on international law documents developed both in ITU, the UN, and the foreign experience of the Republic of Korea, the EU, and the CIS. There was a search and testing of its e-government model. The law gave a legal concept of "electronic public service" as a public service provided with the use of information and communication technologies.

All seven principles of e-government functioning relate to electronic public services: equal access of applicants to electronic public services; provision of electronic public services on the principle of "one window"; unification of documents of state bodies; use of unified identifiers of e-government; continuous improvement of the procedure for providing electronic public services; ensuring information security.

The law establishes state regulation in the field of e-government, regulating in detail the powers of state bodies starting with the Cabinet of Ministers and further along the vertical of executive authorities and local government authorities, and also defines the authorized body represented by the Mininfocom and its rights and obligations.

Considering that today, since 2017, the Ministry of Justice, represented by a specially created Public Services Agency, has played a major role in the provision of public services, it is time to introduce this provision into the law as a separate norm. In its turn, this will show the role of the Ministry of Justice in the state regulation of e-government, especially since this trend will only intensify, emphasizing not only the technological nature, but also the social and legal significance of the development of the egovernment system.

The third chapter of the law is fully devoted to the provision of electronic public services (Articles 18-24) and includes the types of public services, the concept of a Unified Register of electronic Public Services and the fact that the procedure for maintaining it is determined by the Cabinet of Ministers, the requirements for the request for the provision of these services and the response to the requested service, the applicant's rights to receive this service, as well as the procedure for assessing the quality of these services. Thus, the Electronic public service is divided into informational and interactive (v. 18).

Considering that the E-government system was just being formed in 2015, many of its norms were of a reference nature and required serious both technical and organizational and legal steps to implement the provisions of the law.

Therefore, the further development of legislation has followed the path of the adoption of by-laws in the form of resolutions of the President and the Cabinet of Ministers. From a legal point of view, the law is of a framework nature and this was not so much a weakness, but an advantage of the law, which allowed the use of various technologies for the further development of e-government and created the legal basis for the development and interaction of state bodies in the provision of public services.

One of the key acts regulating the provision of electronic public services and important for our analysis is the Resolution of the Cabinet of Ministers No. 728 of September 15, 2017 "On measures to improve the procedure for the provision of electronic public services through the Unified Portal of Interactive Public Services of the Republic of Uzbekistan". This act approved the Regulation on the Single portal of Interactive Public Services, which contains the procedure for the provision of electronic public services through a Single portal of Interactive Public Services. Chapters 3 and 4 of this Regulation are devoted to interactive public services. The Regulation says that electronic public services are being implemented at the Single portal of Interactive Public Services on the basis of the analysis conducted by the Mininfocom in accordance with the criteria for the demand for public services. The procedure and requirements for the provision of electronic public services are determined by the Regulations. It is emphasized that the Regulation is a regulatory legal act and is developed by the state body providing the result of the provision of public services, in coordination with the Mininfocom and serves as the basis for registration of electronic public services in the Unified Register of Electronic Public Services. It lists which provisions should be reflected in the Regulations. The regulations should contain information about the name of the service and a description of the procedures for its provision, which combine three groups of procedures: receiving a request from the applicant; reviewing and processing the request; storing the result and sending a response. Attention should also be paid to the fact that along with the regulations of a particular service, the Provision also obliges the development of a certain Technical Document developed by a state body, but not being regulatory and approved by agreement of the Mininfocom and its structures that ensure the functioning of e-government. An analysis of the content and structure of this Technical Document shows that it contains requirements of legal significance in particular:

category of people to whom the electronic public service is provided;

description of the procedure and stages of the provision of electronic public services; 


\section{The Major Phases and Characteristics of the Development of Legal Regulation Pertaining the Provision of Interactive Public Services in the Republic of Uzbekistan}

technical characteristics of the electronic public service;

graphic representation of the procedure for the provision of electronic public services, taking into account the timing and responsible government agencies;

the cost of providing public services and payment methods (if the service is chargeable);

rights and obligations of the parties when accepting a request from the applicant, reviewing and processing the request, storing the result and sending a response;

the procedure for interdepartmental electronic interaction of relevant information systems of state bodies with a single portal.

The position of the developers of the Regulation is clear which is not to complicate their lives with legal norms.

But a simple enumeration of the requirements for a Technical Document indicates their legal nature. The attempt to separate legal and technical norms does not allow this to be done for two reasons: the first is that they cannot be separated in essence, and the second is that technical solutions still generate legal consequences and are related to the powers of state bodies involved in interdepartmental electronic interaction in the e-government system.

The next stage in the development of e-government deserves attention, associated with the adoption in December 2017 of Presidential Decree No. PD-5278 "On measures to radically reform the National System of public Services to the population", according to which the Agency for Public Services under the Ministry of Justice was established. It is the implementation of the law "On Electronic Government" that has shown that the management, coordination and provision of public services cannot be a purely technological task of the Mininfocom and requires a new level and approach in solving and ensuring a unified state policy in the provision of public services to individuals and legal entities. It can be said that from this moment on, the provision of electronic public services is considered in regulatory legal acts in close connection with administrative procedures. A special place among the resolutions of the President of Uzbekistan is occupied by Presidential Decree No. PD-4193 of February 15, 2019 "On measures for the further development of the national system of public services", which obliged ministries and departments to conduct an inventory of the regulatory framework for regulating specific types of public services and bringing them into line with the law "On Administrative Procedures". The analysis shows that these were acts that linked the provision of public services and their legal regulation with the implementation of the Law "On Administrative Procedures". In addition, it should be noted that this act contained both regulatory and organizational and technical measures, many of which have already been implemented, and therefore today this Resolution is being processed.

In May 2020, Presidential Decree No. UP-5997 approved the Concept of the Development of Justice Bodies and Institutions in 2020-2024, where the implementation of a unified state policy in the field of administrative procedures and the provision of public services was identified as one of the priority areas for the development of the system of justice bodies and institutions. Revealing the content of this direction in paragraph 3, the Concept highlights such tasks as improving the infrastructure of Public Service Centers on an ongoing basis, as well as reducing queues by digitalizing services, developing a unified public services platform, connecting all responsible government departments to this platform. This also includes the development of new directions for improving public services through an annual study of the level of satisfaction of citizens with public services, the gradual expansion of the list of public services provided on the basis of the extraterritorial principle, as well as the provision of the possibility of using them remotely, outside the Republic of Uzbekistan.

In recent years, there has been an expansion of the types of services provided by the Center for Public Services. To illustrate, in 2019, 13 million interactive services were provided with a total of 130 types of services and daily circulation from 300 to 1500 (9). This Decree sets the task of increasing by $12 \%$ the share of public services provided in electronic form. As well as an increase by 15 units in the number of new services provided through public service centers.

Implementing the tasks set out in the Concept, administrative regulations for the provision of public services in the field of social protection have been approved, such public services in the field of social protection as registration of pensions and benefits on the occasion of the birth of a child, issuance of pension certificates, receipt of archival certificates from the registry office have been automated (10). According to administrative regulations, public services are provided only through the Unified Portal of Interactive Public Services, which was launched on July 1, 2013 and operates within the framework of the government portal of the Republic of Uzbekistan on the Internet, including in the "single window" mode.

More than 590 state bodies and their structural subdivisions are connected to the Unified Portal of Interactive Public Services, more than 220 interactive services are provided to the population and business entities.

\section{CONCLUSION}

New technologies, social networks and other means of communication, big data capabilities concentrated in information processing centers are being actively introduced into our lives and public relations, which greatly accelerate administrative and licensing procedures. The development of legal regulation of electronic public services in Uzbekistan is closely related to the level of introduction of digital technologies into the social and economic life of society. Moreover, the law objectively lags behind the 


\section{The Major Phases and Characteristics of the Development of Legal Regulation Pertaining the Provision of Interactive Public Services in the Republic of Uzbekistan}

development of technology. A retrospective analysis of the development of legal regulation of these services makes it possible to identify a number of trends and features characteristic of the Republic of Uzbekistan, which reflect the state's search for adequate models of both technological and digital development and its use in public administration and the choice of an appropriate approach to legal regulation.

First of all, it should be emphasized that basically this regulation is of a subordinate nature and is carried out on the basis of resolutions and decrees of the President.

Uzbekistan is implementing systematic and consistent measures aimed at developing the national telecommunications network, introducing modern ICT into the activities of state authorities and management, improving the infrastructure and legal regulation of e-government.

An analysis of the content of regulatory legal acts concerning electronic public services shows that there is very little law in them, and mostly there is regulation of organizational and technical issues. Digitalization of economic and social relations is not accompanied by an appropriate level of legal regulation. The normative description of digital processes in the development and provision of interactive public services does not fully comply with the requirements of legal regulation. The new digital environment often creates the illusion that legal regulation can be replaced by a set of changing algorithms and not think about the legal consequences of these actions.

Involving the Ministry of Justice represented by the Public Services Agency in the management of e-government is an important step towards improving the provision of interactive public services and developing a unified state policy for the provision of public services.

Finding the right balance, the ratio of the possibilities of legal regulation and administrative and technical solutions in the provision of interactive public services will ensure the rights and freedoms of citizens and the effectiveness of the management process.

Legal science and practice are faced with the task of finding links between classical jurisprudence and new digital technologies in the field of legal regulation of electronic public services.

The existing problems of legal regulation, as well as the ways to resolve them, are both in the field of improving rulemaking and training lawyers specializing in this field.

\section{REFERENCES.}

1) Rubino-Hallman, Silvana, and Nagy K. Hanna. 2006. "New Tech-nologies for Public Sector Transformation: A Critical Analysis of e-Government Initiatives in Latin America and the Caribbean." Journal for e-Government 3 (3): 3-39.

2) Information and Communications for Development 2009: Extending Reach and Increasing Impact. P.88 http://www.worldbank.org/ic4d.

3) Tunisian Program for the Information Society WSIS-05/TUNIS/DOC/6(Rev.1) The concept of WSIS+10 WSIS+10 for the period after 2015 https://www.itu.int.org

4) Geneva Action Plan WSIS-03/GENEVA/DOC/5-R.WSIS+10 Final documents of the high-level event. Geneva, 2014. from 32,38

5) Ibid., p.39.

6) Resolution of the President of the Republic of Uzbekistan No. PD-117 dated July 8, 2005 "On additional measures for the further development of information and communication technologies".

7) DCM No. 181 dated August 23, 2007 "On measures to further improve the interaction of State and economic management bodies, Local Government authorities with Legal Entities using information and communication technologies".

8) No. LRU-395 Collection of Legislation of the Republic of Uzbekistan, 2015, No. 49, Article 611.

9) Decree of the President of the Republic of Uzbekistan No. PD-5930 dated January 31, 2020 "On additional measures to accelerate the development of the national system of public services".

10) No.PD-5930 of 31.01 .2020 "On additional measures to accelerate the development of the national system of public services", PCM No. 327 of May 23, 2020; No. PP-4797 of 04.08. 2020; No. UP-6191 of 03/23/2021. 